\title{
Italian scusa from politeness to mock politeness
}

\author{
Chiara Ghezzi*, Piera Molinelli \\ Università degli Studi di Bergamo, Dipartimento di Lettere, Filosofia, Comunicazione, via Pignolo, 123, 24100 Bergamo, Italy
}

\section{A R T I C L E I N F O}

\section{Article history:}

Available online $\mathrm{xxx}$

\section{Keywords:}

Apologies

Italian

Scusa

Mock politeness

Conventionalization

\begin{abstract}
A B S T R A C T
In Contemporary Italian forms derived from the lemma scus- "excuse" are perceived by speakers as the prototypical realization of the speech act of apology being the most common forms used to apologize and to remedy a breach of etiquette. The same forms are also used to politely ask a permission or to hedge performatives perceived as too direct. In all cases, by using these forms the speakers aim at maintaining or restoring interpersonal relations. However, sometimes scusa and variants do not position the speaker as being regretful, but reinforce dissent, challenge or sarcasm. In such contexts, the forms are used to implement impoliteness or exacerbate an impolite message. Through a corpus of comedies (18th and 21 st centuries), we investigate how the frequency of use of these forms has changed in the centuries. Secondly, we analyse how the mixed nature of apologies, i.e. their strategic and normative values, favours their uses in (im)polite messages, what forms are used to enact them, through mock politeness, and if their frequency has changed with time.
\end{abstract}

(c) 2018 Elsevier B.V. All rights reserved.

\section{Introduction ${ }^{1}$}

In Contemporary Italian $(\mathrm{CI})$ a group of forms derived from the lexeme scus- "excus-" are perceived by the speakers as the prototypical realization of the speech act of apology being the most common, frequent and unmarked forms used to apologize. These apologetic formulae, which are going to be under analysis here, can take on different morphological features as they may include the form scusa "excuse (me)/(I am) sorry/(I beg your) pardon", but also delocutive formulas (e.g. ti faccio le mie scuse "I make (to you) my excuse.PL", (ti) chiedo/domando scusa "I ask (you) excuse"), and verbs (e.g. the delocutive deferent (mi) scusi "excuse.SUBJ.3SG(me)" and scusate(mi) "excuse.IMP.2PL", or the performative mi scuso "PRO.REFL.1SG excuse.1SG"). ${ }^{2}$

As in the case of other types of apologies, these forms are extremely relevant in social interaction since their main goal is that of maintaining or restoring harmony between speaker and hearer (cf. Ogiermann, 2009: 46). To maintain social harmony, they can be used in interchanges, for instance in requests, to ask "license of a potentially offended person to engage in what could be considered a violation of his rights" (Goffman, 1971: 114) and as such they can be considered negative politeness strategies in the sense intended by Brown and Levinson (1987: 131). They can also be used as compensatory actions to restore social harmony in reactions to offences, such as violation of social norms or failure to fulfil personal expectations (Fraser, 1981: 259). In these latter

\footnotetext{
* Corresponding author.

E-mail addresses: chiara.ghezzi@unibg.it (C. Ghezzi), piera.molinelli@unibg.it (P. Molinelli).

1 This research has been carried out by the two authors thanks to the funds of the University of Bergamo. Chiara Ghezzi has benefited from the funds of the project "Cortesia e formalità nel rapporto tra lingue e società: dal latino a italiano e spagnolo (LIS-Cort)" coordinated by Piera Molinelli. We would like to thank here the JoP reviewers, the convenors of the Colloquium "Just how sorry are you mate? Norms and Variations in im/polite language behaviour" Kate Beeching and James Murphy, and all the participants to the colloquium for their precious suggestions and comments. Usual disclaimers apply. Although this article is the result of a continuous collaboration between the two authors, for the purposes of Italian academia, Piera Molinelli is responsible for writing Sections 1 and 2, and Chiara Ghezzi of Sections 3-5.

2 Cf. Benveniste (1958) for the notion of delocutive verbs and formulae.
} 
use Leech (1983: 125) defines them as transactions involving a "bid to change the balance-sheet of the relation between $s$ and $h$ ". This imbalance is created by $s$ committing an offence harming $h$, and $s$ 's apology constitutes an attempt at restoring the balance.

Therefore, depending on their pragmatic function, they can be used either as "substantial" or as "ritual" apologies. While the motivation for the former is genuine regret for an offence, the latter aims at fulfilling social expectations (Ogiermann, 2009: 47). In this latter function they are performed in order "to evince good manners, to assuage the addressee's wrath, or simply to get off the hook and be on one's way" (Norrick, 1978: 280). ${ }^{3}$

As is evident from the examples below, while in (1) the apology is motivated by genuine regret for the committed offence, i.e. trying to slip a sleeve on the wrong person, in (2) the use of scusa aims at fulfilling social expectations, i.e. the polite request for a repetition.

(1) Turi: [...] guarda che mi stai infilando la manica della tuta.

'Turi: look, you're slipping the tracksuit sleeve on my arm'

Maria: (impacciata) Scusa, scusa, è che non si vede granchè (Mannarano, Due etti possono bastare)

'(awkward) Sorry, sorry, I can't see that much'

(2) Scusa, amore, non ho capito. Avete parlato di cosa? (Saverino, Arcobaleno di figli)

'Excuse me, honey, I didn't understand. You were talking about what?'

However, the distinction between genuine and ritual apologies is fuzzy as an apologetic speech act often combines both aspects which imply normative as well as strategic elements of politeness (cf. Fraser, 1981: 266 and Ogiermann, 2009: 48). Uttering the appropriate formula under the circumstances requiring it can be viewed as an aspect of normative politeness codified by a society. Engaging in considerations regarding the future relationship with the offended party or one's reputation and weighing them up against the humiliation involved in admitting responsibility for the offence are strategic means used by the speaker to maintain social harmony.

Because of this ambiguity, speakers can employ these same forms in some contexts to enact specific types of impoliteness. In such uses the forms do not position the speaker as being regretful, but instead seem to reinforce dissent, challenge (ex. 3 ) or sarcasm (ex. 4).

(3) E no! [...] queste cose che dice tuo padre non mi sognerei mai di farle, eh, scusa (Chinnici, Se riesce siamo ricchi, 2005)

'Well, no! [...] I would never dare do what your father says, excuse (me)'

(4) Ma lei, scusi, che vuole, che sta a rompere gli stivali? Si faccia i fatti suoi (Bertarelli, Il gioco del lotto, 2011)

'Excuse (me), what do you want? Why are you getting on my nerves? Mind your own business'

As examples (3) and (4) above show, speakers employ the norms associated with the use of the forms strategically to implement impoliteness and exacerbate an impolite message (Culpeper, 2011: 178).

Among these forms, the expressions scusa, and to a lesser degree its deferent counterparts scusate/scusi, have a higher degree of conventionalization, as they are partially bleached and are used in recurring contexts as canonical examples of 'politic' behaviour. ${ }^{5}$ These forms have become socially institutionalized and speakers can use them to demonstrate etiquette and appear polite within an ongoing social interaction (cf. also Watts, 2003: 19). Speakers consider these expressions as socially 'conventional' in a wealth of basic norms of good manners (e.g. after sneezing, when getting up from the table before the end of the meal, etc.), ${ }^{6}$ but with similar functions speakers also use them to organize discourse (e.g. to manage turns, scusa se t'interrompo "I am sorry to interrupt you", or to get the interlocutor's attention, scusa, siamo già a Milano? “Excuse (me), are we already in Milan?").

Moving on from these premises, this study aims at analysing.

1. if it is possible to identify variations in time in the use of forms derived from the lexeme scus-as means to convey a polite message;

2. how the mixed nature of apologies, i.e. their strategic and normative values, favours their uses in genuinely polite as well as in ironic or sarcastic speech acts (mock polite);

3. what forms in particular are also used to enact linguistic impoliteness, through mock politeness, and if it is possible to find variations in such uses with time.

For a number of reasons, to verify these hypothesis we have analysed a corpus of comedies written in the 18 th and the $21 \mathrm{st}$ century, respectively. First of all, comedies mimic spoken language and sociolinguistic norms (and variations) of the historical period which is being put on stage. Therefore we are directly exposed to the words and actions of characters which are meant not only to convey messages to other characters, but also the playwright's message to the audience (Culpeper, 2001: 39).

\footnotetext{
${ }^{3}$ On the ritual and social function of apologies see also Zimin (1981) and Coulmas (1981).

4 The examples in this paper are taken from a corpus of comedies written in the 21st and 18th century, respectively. For details on the peculiarities of the corpus see $\S 3$.

5 According to Watts (2003: 115) “politic behaviour consists in 'paying' with linguistic resources what is due in a socio-communicative verbal interaction".

6 Cf. also Dardano e Trifone (1997: 87), Bozzone Costa et al. (2014).

7 Cf. Businaro (2002: 290).
} 
Secondly, it is a genre in which (im)politeness features, either as a result of social disharmony or as the cause of it, can be a central textual technique in characterization (Culpeper, 2001: 261).

This paper is structured as follows: in Section 2 we describe the background of apology formulae in $\mathrm{Cl}$ as we take into consideration the different components that characterize apologies; we also describe how the different forms derived from the lexeme scus-can be used today to implement impoliteness. In Section 3 we describe the corpus and the methodology used for the coding of data, while in Section 4 we present the results of data analysis and in Section 5 we come to some conclusions.

\section{Background}

\subsection{Apologies in Italian}

Apologies can be considered transactions that give value to the interlocutor as they represent "an acknowledgement of an imbalance in the relation between speaker and hearer, and to some extent an attempt to restore the equilibrium" (Leech, 1983: 125). Therefore, their prototypical functions relate to maintaining the congenial relationship between the interlocutors to avoid or mitigate possible conflicts between them or to restore this relationship once affected by some offences. In order to restore $h$ 's face damaged by the offence, $s$ performs a speech act which is costly to his or her own face, which makes apologies "face-saving for the $h$ and face-threatening for the $s$ " (Olshtain, 1989: 156).

However apologies can also be used as means of image restoration which relate to the speaker's face needs as the purpose of an apology is not only to placate the hearer, but also to restore one's own social status (cf. Ogiermann, 2009: 47, see also Fraser, 1981: 259 on the same point).

Some felicity conditions can capture the vast majority of utterances described as "apology speech-acts" (cf. Murphy, 2015a, cf. also Leech, 2014: 118 for the description of the semantic frame of the nucleus of an apology and of its satellite speech events).

It is possible to describe prototypical apologies in terms of (a) propositional content: an act done, or to be done in the future, by the speaker or someone for whom the speaker is a formally recognised representative; (b) preparatory condition: the speaker believes that the apology recipient, or a contextually relevant third party, believes that the act was an offence against the recipient (or someone who the recipient represents; (c) sincerity condition: the speaker regrets the act or one of its consequences (d) essential condition: utterance counts as an apology.

As Deutschmann (2003: 46) underlines, considering prototypical apologies from this perspective, makes it possible to identify four components, i.e. an offender, who takes responsibility for the offense but did not necessarily cause it, an offended, who is perceived to have suffered as a result of the offense, an offense-real, potential, or perceived as such by the offender or the offended, a remedy-recognition of the offense, acceptance of responsibility, and a display of regret.

All these conditions are at work in example (5) below.

(5) Anto: E non fare cose che mi spaventi

'Don't scare me!'

Lotu: Hai ragione, scusa (Scarpelli, La banda degli onesti)

'You are right! Sorry'

In (5) Lotu has done something that has scared Anto (propositional content - offense). Lotu (the offender) acknowledges that he has somehow offended Anto (the offended) with his act (preparatory condition). He regrets having done this act (sincerity condition) and therefore he apologizes (essential condition - remedy).

However, apologetic speech acts do not constitute clear-cut categories but rather prototype ones. Therefore it is possible to identify a number of non-prototypical apologies which are relevant along the continuum politeness-impoliteness.

Differently from prototypical (or 'pure') apologies, non-prototypical ones represent some kind of subordinated action which performs some kind of secondary action (cf. Robinson, 2004: 297). In this type of 'mixed messages', the apologetic forms seem to function as alerters, i.e. "element[s] whose function is to alert the Hearer's attention to the ensuing speech act" (Leech, 2014: 122, Blum-Kulka et al., 1989: 277).

While in (5) the apology token scusa is the foregrounded action and is used exclusively to perform an apology, in (6) scusi is subordinated to the primary action which is requesting information. An evidence of this is the difference in translations that characterises the two different apologetic speech acts: in (5) scusa can be translated with "sorry", while in (6) scusi can only be translated with "excuse me".

(6) Scusi, come ha detto che faceva di cognome questa signora? (Giunti, Il diavolo e il sagrestano)

'Excuse (me), what did you say this Lady's surname was?'

In $\mathrm{Cl}$ the head act of apologies, i.e. the apology itself, can be modulated and modified through intensification which adds attitudinal and emotive meaning (e.g. scusa tanto "I am really sorry" in ex. 7). Similarly, apologies can also be downgraded in an attempt to minimize an offence (for instance the interruption of Margherita in ex. 8 can be mitigated by the use of scusa un attimo "excuse me for a minute/moment"). 
(7) Bussata di porta (campanello) Annuccia (va ad aprire): Uffà!... (Voce fuori campo - tono seccato) Ah, Rafè, si' tu? Rafele (voce fuori campo): E scusa tanto !.... Gennarino ce stà? (Andolfi, 1997, Il caso è così) 'Knocking on the door (the doorbell rings) Annuccia (opens the door): Ugh!...(voice-over - annoyed tone) Oh, Raffaele, is that you? Raffaele (voice-over): Oh, my apologies! Is Gennarino there?'

(8) Margherita: Quando ne parlo bene! Dicevo, dato che io sono singola e non ho mai avuto in casa dei ragazzi ... (viene interrotta). Mariolina. Scusa un attimo Margherita. Hai appena detto che ci chiami ragazze quando parli bene di noi. E quando ne parli male invece? (Cattaneo, Le sorelle trapunta)

'Margherita: When I speak well of you! I was saying, since I'm single and I've never had boys in the house ... (is interrupted).

Mariolina: Excuse me for a moment, Margherita. You just said that you call us girls when you speak well of us. And when you speak ill instead?'

Apologies can take the form of a vast number of strategies which would be difficult to enumerate in detail here. ${ }^{8}$ However speakers seem to prefer strategies with a fixed form that they tend to use recurrently. As a matter of fact, this type of apologies represents the highest percentage (83\%) of apologetic formulae (cf. Aijmer, 1996: 82). In CI such polite apologies include conversational rituals derived from utterances having the lemma scus-as a starting point (see Table 1).

Table 1

Apologies in $\mathrm{CI}$.

Performative locutions

Performative verb

Delocutive verbs

\author{
chiedo/domando scusa "I ask excuse.F.SG" \\ mi scuso "PRO.REFL.1SG excuse .1SG" \\ informal: scusa(mi) "excuse.IMP.2SG (PRO.ACC.1SG)" \\ scusate(mi) "excuse.IMP.2PL (PRO.ACC.1SG)" \\ deferent: (mi) scusi "excuse.SUBJ.3SG (PRO.ACC.1SG)" \\ scusate(mi) "excuse.IMP.2PL (PRO.ACC.1SG)" \\ (Southern varieties) ${ }^{9}$
}

These forms include (a) performative locutions as chiedo scusa (ex. 9), the performative verb mi scuso (ex. 10), the delocutive verbs scusa(mi)/scusate(mi) (ex. 11-12) and their deferent variants (mi) scusi/scusate(mi) (ex. 13).

(9) Va bene. Mi dispiace. Le chiedo scusa (Cavalletto, Alloggio con vista)

'All right. I am sorry. I apologize'

(10) Le giuro, ho fatto un terribile errore. Mi scuso ancora (Veneziano, Scusi, Lei ucciderebbe mio marito?)

'I swear, I made a terrible mistake. I apologize again'.

(11) Scusami, cosa volevi da me? (Sapienza, Permette? Angelo Musco, artista)

'I was a bit distracted, (I am) sorry. What did you want from me?'

(12) Gino: No, che ti sbagli! È la mia [valigia]! 'No, you're mistaken. It's mine [the suitcase]

Orazio: Oh scusa !... 'Oh, (I am) sorry' (Boscolo, Viva i parenti)

(13) Ah, lei oggi è qui solo di passaggio...Scusi solo un secondo (Cavalletto, Leila)

'Ok, you are just a visitor here. Excuse me just one second sir'

As Businaro (2002: 481-2) notes, it is relevant to highlight the difference between the transitive verb scusare (from which the forms scusa "excuse.IMP.2SG", scusate "excuse.IMP.2PL", and the deferent scusi "excuse.SUBJ.3SG") and the reflexive verb scusarsi (from which mi scuso "PRO.1SG excuse.1SG", scusami "excuse.IMP.2SG.PRO.1SG", scusatemi, "excuse.IMP.2PL.PRO.1SG" mi scusi "PRO.1SG excuse.SUBJ.3SG"). In CI the reflexive verb represents the canonical and grammatically correct form. However today the most conventionalized apologetic speech acts are the crystallised forms of the transitive verb scusare (i.e. scusa, scusi, scusate) which are semantically equivalent to the reflexive scusarsi. Among the three forms scusa seems to have the highest degree of conventionalization as it has acquired a 'bleached' meaning and reduction through ellipsis (ti chiedo scusa lit. 'I ask excuse to you' > scusa). This expression has partially lost its grammatical status as speakers are often in doubt on its grammatical status and may consider it a noun (a reduced version of ti chiedo scusa) or a verb (a reduced version of scusami) (cf. also Leech, 2014: 124 on similar uses of Eng. pardon and sorry).

Both the transitive and the reflexive verb are documented in Old Italian with the meanings "exonerate, cancel (a debt), oppose a refusal, pretend to be", none of which reflecting the use of CI 'to apologize' (cf. TLIO s.v.).

The use of the crystallized form scusa in apologies is not registered until the beginning of the 19th century. It is possible to find examples of this use in texts in the first half of the 19th century, as in the case of ex. 14 from a letter of the poet Giacomo

\footnotetext{
${ }^{8}$ A number of scholars have focused on taxonomies of speech acts used to apologise, cf. for instance Fraser (1981: 263) or Olshtain and Cohen (1983). Aijmer (1996) distinguishes 13 apologizing strategies which include macro distinctions between explicit vs implicit apologies which can be further subclassified into emotional vs non-emotional apologies. Explicit emotional apologies are for instance explicit apologizing (I apologize for) or expressing regret (pardon me, excuse me), non-emotional ones are acknowledging a debt (I owe you an apology) or demanding forgiveness (I beg your pardon). On the contrary implicit emotional strategies include giving an explanation or account ((I'm sorry) it's so unusual) while implicit non emotional apologies include for instance minimizing responsibility (I didn't mean to...I thought this was... I was thinking it was). For the Italian language in particular strategies may include, among others, the use of modals and tenses (volevo scusarmi 'I wanted to apologize') or of a number of verbs as sbagliare 'mistake', perdonare 'forgive', dispiacersi 'to be sorry'. Cf. Businaro (2002) for a detailed list of different strategies used as apologies in Italian.

${ }^{9}$ In Contemporary Italian the standard deferent form is (mi)scusi, the form scusate(mi) is a deferent variant which can be used instead of deferent ( $m i$ ) scusi in Southern varieties. Note that scusate( $\mathrm{mi}$ ) can also be used as the plural variant of informal scusa(mi) (2SG) to address more than one person especially by speakers of Central and Northern varieties. However, in our data we have considered tokens only of the deferent use of scusate(mi).
} 
Leopardi dating 1830. Dictionaries of the time register uses similar to those of today and acknowledge other crystallized variants (e.g. scusi) under the lemma scusare "excuse.INF". The same dictionaries also register uses with ironic connotations (cf. below for other less prototypical functions and $\S 2.2$ for ironic and sarcastic uses) ${ }^{10}$.

(14) Scusa la mia brevità. Sai che non posso più scrivere. (Leopardi, Epistolario, ad A. Papadopoli, 1830) 'Excuse my brevity. You know I cannot write anymore'

In $\mathrm{CI}$ these forms can perform a range of different polite functions which cluster around the redressive value of the formulae. In their genuinely apologetic use they position the speaker as 'feeling bad' about an action and wishing to repair a 'potential' damage to interpersonal relations with an interlocutor (Murphy, 2015b; Businaro, 2002).

Speakers can also use these forms to remedy a past or immediately forthcoming breach of 'etiquette' or other minor offenses (e.g. mitigating a request (ex. 15), interrupting (ex. 16), refusing...).

(15) Buon giorno, dottore. Mi scuso se sono un po' invadente. Ho urgente bisogno di parlare con il professore [...] (Bertarelli, Il cibo della felicità)

'Good morning doctor. I apologize if I'm a bit pushy. I urgently need to talk to the professor'

(16) Signor parroco, scusi se la interrompo, ma le volevo chiedere se quando andiamo in gita la prossima volta, potrebbe portarci a "Internet"? (Cattaneo, Il censimento. La serva del parroco e la cameriera)

Father, excuse my interruption, but I would like to ask you if when we go on an excursion next time can you take us to the 'Internet'?

Speakers can also use the same forms to mitigate a criticism or a disagreement (ex. 17).

(17) Mamma, scusa ma ti sbagli, il tè è per me e non per te. (Cattaneo, Si inizia sempre dal Pronto Soccorso)

'Mum, I am sorry but you are mistaken, the tea is for me, not for you'

Alternatively, speakers can use these forms to take the turn and get the interlocutor's attention for instance to ask a question (cf. ex. 2 above).

Finally, speakers can use these forms to take some time for ongoing planning or to correct themselves (18).

(18) Fantastico. Vedrai che mi aumenterà la rendita. Oh scusa volevo dire ci aumenterà (Tassara, Un grazioso viavai)

'Fantastic. You'll see that he will increase my income. Oh sorry I meant he will increase our income'

This polyfunctionality is a clue to the fact that today some forms, namely scusa, and less markedly also the deferent scusi/ scusate, seem to have entered a conventionalization cline and have become partially bleached of their original propositional content.

\subsection{Apologies and (im)politeness in Contemporary Italian}

As discussed in Section 1, the apologies focused on here are described as interactional rituals, i.e. standardized ways of managing interpersonal encounters, organized according to socio-cultural norms that regulate the appropriate behaviour of its members. Therefore speakers assign a positive evaluation to an action, i.e. they consider it polite, when it is in congruence with the expected norms in force in that society, while they assign a negative evaluation to actions, i.e. they judge them impolite or rude, when they are contrary to those norms (Fraser, 1990: 220).

The high polyfunctionality of forms derived from scus-as described in $\S 2.1$, supports the importance of analysing their uses and functions in different contexts from the perspective of the continuum politeness - impoliteness. More precisely, the frequency of these forms in a number of different contexts together with their degree of conventionalization, may have a role in the use of the same forms not only in polite apologies, but also in impolite messages, especially through mock politeness.

In $\mathrm{Cl}$ apologies containing a form derived from scus-can be used in four subclasses of (im)polite messages along the continuum $[+$ polite $]>[- \text { polite }]^{11}$

The first subclass includes uses which convey a polite message. In such uses forms are employed with functions that represent 'genuine' instances of 'pure' apologies as described in $\S 2.1$ (cf. also example 5 above).

\footnotetext{
${ }^{10} \mathrm{Cf}$. Tommaseo and Bellini s.v. where scusi is considered an example of a deferent politeness strategy or of usual ceremony and sometimes of irony (e.g. Scusi la mia sincerità "excuse my sincerity", Scusi, si va egli bene di qui in piazza della Signoria? "Excuse-me is this the right direction for Piazza della Signoria?", Oh, Scusi! Scusi, sa? "Oh, excuse me, excuse me, you know?" especially if someone is saying something that does not require an apology but the interlocutor seems offended).

${ }^{11}$ The different types of messages and their (im)polite meanings are exemplified in this section through the form scusa, which is the most frequent among all the forms derived from the lemma scus-. All other forms derived from the same lemma can however be used in similar contexts and with similar meanings, but with variable frequency as will be described in $\S 4$.
} 
The second subclass includes the so-called 'mixed messages' in which speakers use the apologetic form to perform some type of secondary action. This subclass includes.

(a) formulaic apologies in which the act of apologizing is 'politic' and, therefore, more or less a matter of routine, e.g. saying sorry for social gaffes such as coughing, slips of the tongue, closing a telephone conversation, etc. (ex. 19);

(b) formulaic apologies with added functions in which the offense is minimal and the apology itself has other functions in addition to repair work, e.g. cueing a request, or calling for attention (ex. 20);

(c) face attack apologies which preface a speech event that is likely to be seen as impolite, such as a directive, a refusal, a complaint or criticism (ex. 21). ${ }^{12}$ These last uses cannot be considered impolite, as the polite move, i.e. the apology itself, encompasses the impolite move, e.g. the criticism, and thus there is no mismatch of im/politeness.

(19) (Al cellulare) scusa Amilcare ora ti devo lasciare [...]. (Chiude la telefonata). (Catteneo, Siamo diventati tutti virtuali) '(on a mobile phone) Sorry Amilcare I have to leave you now [...].(He ends the conversation)'

(20) Aldo, scusa ... hanno suonato... che faccio? (Macri, Non si scherza con quella signora) 'Aldo, excuse me, they rang the doorbell, what shall I do?'

(21) Sì Giangi, lo so che tu avresti voluto fare qualcosa, ma, scusa se te lo dico, non avevi proprio gusto (Settele, I particolari fanno la differenza).

'Yes, Giangi, I know you would have wanted to do something, but I am sorry to say you did not have any taste.'

In these type of messages scusa is often used as a preface to a face threatening act (FTA) in this way. In many contexts the speaker seems to justify her/his own behaviour by a following or, less frequently, preceding ma "but". In such contexts scusa could be elaborated as follows: "I'm sorry that I'm going to say/do something unpleasant to you..." and its effect is to slightly mitigate the impoliteness of the FTA. The use of $m a$ is also significant, and can be explicated as follows: "I'm sorry, but despite that, I'm going to say the unwelcome thing that I have to say." (cf. also Leech, 2014: 119 on similar uses of apologies in English). In Italian the formula is particularly frequent and belongs to a series of other constructions with the model [adversative $m a+$ imperative verb]. ${ }^{13}$

The third subclass includes 'mock' polite messages, i.e. messages which have "an impoliteness understanding that does not match the surface form or semantics of the utterance or the symbolic meaning of the behaviour" (Culpeper, 2011: 17). In these messages "an ostensibly polite stance, which is indicated through the occurrence of a (non-)linguistic form or practice that would in other circumstances be associated with a polite attitude, masks or disguises an 'impolite' stance that arises through implicature" Haugh (2014:278). Such uses represent instances of 'pragmatic mismatches', i.e. "mixed features which point towards a polite interpretation and features that point towards an impolite interpretation", therefore leading to an implication of impoliteness (cf. also Culpeper, 2011:165-166, Taylor, 2016: 18).

(22) Petralia, faccia passare la monaca zitella, chiedo scusa, volevo dire la signorina Cesira

(Schirinzi, Anche la verità può avere i baffi)

'Petralia, please let the old maid nun in, I beg your pardon, I meant Mrs. Cesira'

In (22) the character takes an ostensibly polite stance by using chiedo scusa and by correcting himself in relation to his comment on the arrival of the Signorina Cesira (a character that prototypically represents the stereotype of a spinster). This behaviour however masks his impolite stance based on the use of the terms monaca zitella 'old maid' which have a negative connotation, therefore leading the hearer to a mock polite interpretation.

The last subclass of messages include 'genuinely' impolite utterances. In these contexts, the speaker apologizes to implement a negative attitude towards behaviours occurring in specific contexts. "[...]Situated behaviours are viewed negatively - considered 'impolite' - when they conflict with how one expects them to be, how one wants them to be and/or how one thinks they ought to be. Such behaviours always have or are presumed to have emotional consequences for at least one participant, that is, they cause or are presumed to cause offence" (Culpeper, 2011: 23).

\footnotetext{
${ }^{12}$ A refusal and or complaint/criticism would violate some of Leech's Politeness maxims (1983: chapter 6). The first would violate the Tact maxim (Minimize the expression of beliefs which imply cost to others [...]), while the latter would violate the Approbation maxim (Minimize the expression of beliefs which express dispraise of others[...]). On the topic cf. also Deutschmann (2003), Culpeper (2011) and Leech (2014).

${ }^{13}$ These constructions can be interpreted as interesting cases of collostructions. For a detailed analysis of some Italian collostructions based on this model see Fedriani and Molinelli (2017).
} 


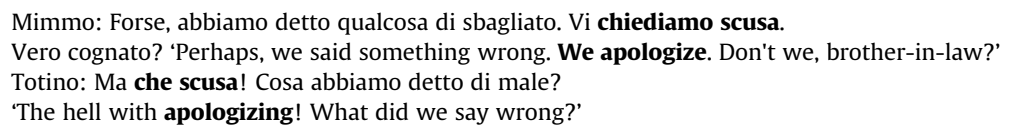

In (23) Mimmo believes he and Totino have said something offensive to Peppina and apologizes to her also on behalf of Totino. On the contrary, Totino does not agree with him and impolitely refuses to apologize. By explicitly refusing to apologize he behaves contrary to what would be expected in such a situation, therefore causing an offence to Peppina.

Even though some forms seem more conventionalized than others, it is not possible to use them in messages mocking impoliteness as all the forms still retain, partially or totally, their apologetic meaning which is obviously conflicting with a mock impolite message.

\section{Corpus and methodology}

The corpus used in the data analysis comprises a selection of comedies written during the 18th and the 21st century, respectively.

The choice of the textual genre of comedies is not random, but was determined by the fact that we needed to analyse texts that were comparable across the centuries and that could in some ways represent a replica of actual spoken language. We believe the genre of comedy plays to represent such type of texts although we are aware of the fact that in many circumstances their mimesis of spoken language can be highly stereotyped. However, the language found therein could represent a comparable and acceptable approximation of the language actually used in the society depicted in each century considered.

Moreover, this textual genre seems particularly suited for an analysis on mock politeness as in addition to the language used by characters it also includes side comments and metacomments which make it easier to identify cases of mock politeness. Nevertheless, we are aware of the fact that like in all kinds of irony and sarcasm, where there is a paradox between forms and meaning, in many cases the interpretation of data refers to situations and contexts which are subjectively interpreted with our actual eyes and which therefore imply an etic and not an emic interpretation.

The 21st century corpus of plays was compiled through webcrawling (cf. Suchomel and Pomikálek, 2012). It comprises 367 contemporary plays with a total 4,430,235 words. On the contrary, the 18th century corpus comprises a selection of Goldoni's comedies, specifically 67 comedies, with a total of 1,079,154 words.

Considering the high number of occurrences of the forms, particularly in the 21st century corpus, where the form scusa alone has approximately 1600 occurrences, only the first 100 occurrences were considered after having shuffled results as to avoid all the results from the same play.

As far as methodology is concerned, the analysis of the corpora has taken into consideration the different type of messages in which characters use apologies derived from the lemma scus-on the basis of the theoretical background described in $\S 2.1$ and 2.2, respectively. Therefore, we have considered the correlations between the different forms derived from the lemma scus- and their function in terms of politeness.

Firstly, we have considered the correlations between forms and type of messages - polite, mixed, mock polite, impolite on the basis of the categories identified in §2.1. Secondly, for mixed messages in particular which represent the highest number of occurrence of apologies, we have also considered the correlations between forms and functions of apologies.

Finally, we have analysed both type of data in the light of the diachronic developments of the forms.

For the analysis of different types of messages we have carefully considered the surrounding context in the comedies in which the apologetic form itself is used, e.g. the presence of other functions in addition to repair work or of metacomments which may be useful in indicating a mock polite interpretation, however we are aware that nevertheless the identification of different types of messages rests on our personal interpretation.

\section{Results: strategies of (im)politeness in the plays}

The different degrees of conventionalization of the forms derived from the lemma scus-have also a correlate in their frequency of use. A preliminary quantitative survey of the forms gives an insight into their distribution within the two corpora (cf. Table 2).

Table 2

Normalized frequencies of forms derived from the lemma scus-in the comedies.

\begin{tabular}{|c|c|c|c|c|c|}
\hline 21st century & Occurrences per million words & $\%$ & 18th century & Occurrences per million words & $\%$ \\
\hline Scusa & 260 & $30 \%$ & Scusa & 0 & $0 \%$ \\
\hline Scusi & 204 & $24 \%$ & Scusi & 9 & $7 \%$ \\
\hline Scusate & 144 & $17 \%$ & Scusate & 23 & $18 \%$ \\
\hline Mi scusi & 124 & $14 \%$ & Mi scusi & 9 & $7 \%$ \\
\hline Scusami & 58 & $7 \%$ & Mi scusa & 1 & $1 \%$ \\
\hline Scusatemi & 33 & $4 \%$ & Scusatemi & 39 & $30 \%$ \\
\hline Chiedo scusa & 33 & $4 \%$ & Chiedo/domando scusa & 46 & $36 \%$ \\
\hline Mi scuso & 3 & $0 \%$ & Mi scuso & 1 & $1 \%$ \\
\hline Total & 859 & & Total & 128 & \\
\hline
\end{tabular}


The most frequent form in the 21st century is informal scusa (30\%), followed by deferent scusi (24\%), and by its deferent Southern variant scusate (17\%). Corresponding reflexive verb forms are less frequent (mi scusi (14\%), scusami (7\%) and scusatemi (4\%), respectively). The performative locution chiedo scusa and the performative verb mi scuso are the least frequent of all.

In the 18th century the most frequent expression is the performative locution chiedo/domando scusa (36\%), followed by the deferent scusate (30\%) and by the reflexive scusatemi. Note that both expressions are used as deferent forms of address in concurrence with scusi or mi scusi, which are however less frequent (7\%). Differently from what happens in the 21st century, this alternation does not represent a geographically-based variation but both forms were used by the same people. In the 18th century the Italian system of address was reconfiguring and two different deferent forms were at work, i.e. second-person plural address, to show respect, and third-person singular address to show deference (see Molinelli, 2015). It was possible to find only one occurrence of the performative verb mi scuso (1\%) and of the informal mi scusa (1\%). All in all expressions derived from the lemma scusa were less frequent than today as other concurring expressions, derived from other lemmas, were also at work as for instance perdono 'pardon' and compatire 'pity.INF'.

In actual fact Held (2005: 292ff.) has highlighted that the 18th century is characterized by a ceremonious etiquette which implies the use of a much wider and complex inventory of fixed phrases and routine formulae. The act of apology, the socalled complimento di scuse 'apologetic compliment', had a very strict normative etiquette and was codified in great detail. ${ }^{14}$ Note in (24) from one of Goldoni's comedies how the master is disappointed by the fact that his servant has apologized without his consent.

(24) OTT. Del servitore parla più niente?

"No news from our servant?"

PANT. Anca per questo la xe giustada. El gh'ha domandà scusa, e la xe fenia.

"We have solved everything. He apologized and everything is fine now"

OTT. Senza mio ordine ha domandato scusa? Lo caccerò via

"Did he apologize without awaiting my order? I will send him away!"

A comparison of the use of apologetic formulae derived from scus-in the two centuries offers interesting insights (cf. Fig. 1).



Fig. 1. Apologies from the lemma scus-in the 18 th and 21 st century.

In the 18th century the delocutive verb scusate ( $\mathrm{mi}$ ) and the performative locutions chiedo/domando scusa were the more frequent forms while in the 21st century the more frequent forms were the formal delocutive(mi) scusi, informal scusa(mi) and the deferent Southern variant scusate $(\mathrm{mi})$. These data suggest an important difference in the strategic uses of apologies in the two centuries. In the 21st century speakers seem to prefer expressions which have a lower degree of personal commitment and agency (e.g. scusa, scusi, scusate) and which tend to focus on the hearer. On the contrary in the 18th century one of the most frequent expressions is chiedo scusa, a performative verb focussing on the speaker, with a higher degree of agency and personal commitment.

A more detailed analysis of the correlation of different forms with the type of polite message in which they are used gives other interesting insights in relation to the 21st century (see Table 3 and Fig. 2, respectively).

More frequent forms used in genuinely polite messages are the performative verb mi scuso and the informal imperative scusami, interestingly deferent variants such as scusi or scusate are less frequent in polite apologies (ex. 25).

\footnotetext{
14 The complimento di scuse, as it is named by speakers of the time and by the many manuals of etiquette, was part of a complex system of rules of linguistic etiquette. As Tosi (2001: 75-76) notes, many of Goldoni's comedies are based on the pretensions of social parvenus trying to adopt aristocratic manners and behaviour, but whose inadequate command of the linguistic ceremonies of the upper classes reveals their humble origins. As Goldoni himself explained for the new élites it is not easy to speak well and especially it is not easy to seem courteous without being overly ceremonious.
} 
(25) La saluto don Orazio, e...scusi tanto se le lascio lì le scarpe (Chinnici, Sogno strano e terno secco). 'I bid you farewell don Orazio and I really apologize if I leave my shoes over there on you'.

Table 3

(Im)politeness in 21st century comedies.

\begin{tabular}{|c|c|c|c|c|c|c|c|c|}
\hline XXI & scusa & scusami & scusi & mi scusi & scusate Voi-deferent & scusatemi Voi-deferent & chiedo scusa & mi scuso \\
\hline Politeness & $35 \%$ & $51 \%$ & $10 \%$ & $19 \%$ & $9 \%$ & $18 \%$ & $20 \%$ & $54 \%$ \\
\hline Mixed messages & $51 \%$ & $41 \%$ & $59 \%$ & $55 \%$ & $62 \%$ & $54 \%$ & $39 \%$ & $7 \%$ \\
\hline Mock politeness & $11 \%$ & $8 \%$ & $31 \%$ & $26 \%$ & $29 \%$ & $28 \%$ & $36 \%$ & $39 \%$ \\
\hline Impoliteness & $4 \%$ & $0 \%$ & $0 \%$ & $0 \%$ & $0 \%$ & $0 \%$ & $4 \%$ & $0 \%$ \\
\hline Total & 100 & 100 & 100 & 100 & 100 & 100 & 100 & 100 \\
\hline
\end{tabular}

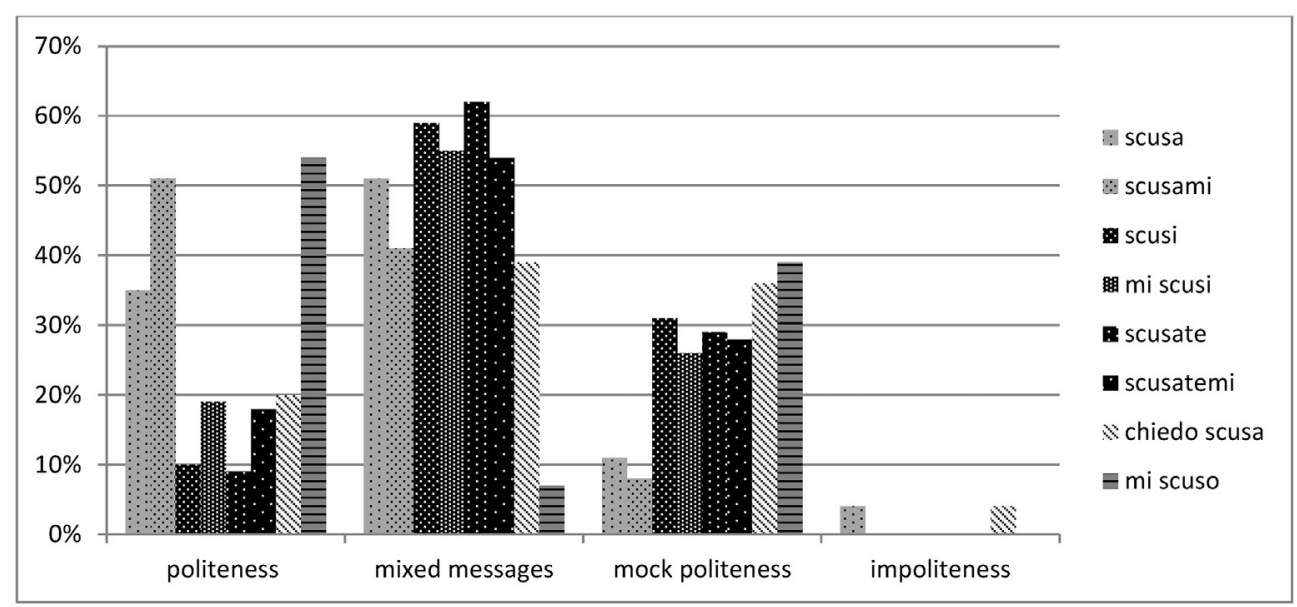

Fig. 2. (Im)politeness in 21 st century comedies.

On the other hand, more deferent forms such as mi scuso, scusi, scusate and chiedo scusa, are more frequently used with a mock politeness value (ex. 26-27). In (26) the sarcasm is based on the use of the term zitella 'old maid', which has a negative connotation and is used to comment on a rather hysterical reaction from the Signorina Graziella. In (27) instead sarcasm is addressed to a character who is praising South American cuisine.

(26) Scusi dimentico sempre che è rimasta zitella! (Conti, Parcheggio a pagamento)

'(I am) Sorry, I always forget that you are an old maid'

(27) LILIANA (ai genitori) ci penso io. Mi scuso nel dirle che da noi non si usa questo cibo, ma posso farvi assaggiare un bel risotto alla milanese. Va bene?

'(to her parents) I'll sort this out. I apologize in saying that we do not eat this type of food, but I can offer you a nice Milanese risotto. Ok?'

It is also relevant to note how mixed messages, as defined in $\S 2.2$, represent the majority of occurrences of the forms under analysis, with the sole exception of mi scuso. Their frequency is particularly marked for scusa, mi scusi and scusi.

These forms can be used to introduce a variety of situations such as: requests or refusals, criticisms or disagreements (28), interruptions (29), questions (30).

(28) Scusi la mia franchezza, ma noi uomini d'arme usiamo gli aggettivi che centrano il bersaglio come un buon colpo di cannone. (Bertarelli, Il cibo della felicità)

'Excuse my frankness, but we men-at-arms use adjectives that hit the target like a cannon shot'.

(29) Scusa se ti interrompo Teresina, come sai tu che in paradiso ci sarà San Pietro e non ... San Paolo? (Cattaneo, In Paradiso scelgo io)

'Excuse me if I interrupt Teresina, how do you know that Saint Peter will be in heaven and not Saint Paul?

(30) scusa la mia domanda indiscreta...quanti soldi tieni in tasca? (Silvestri, Vieni all'happy hour?)

'Excuse my indiscreet question... how much money do you have in your pocket?'

Table 4 and Fig. 3 (respectively) display different frequencies of forms in mixed messages.

Table 4

Mixed messages and functions in 21st-century comedies.

\begin{tabular}{|c|c|c|c|c|c|c|c|c|c|c|c|c|}
\hline XXI & mi scuso & $\%$ & mi scusi & $\%$ & scusi & $\%$ & scusa & $\%$ & scusami & $\%$ & chiedo scusa & $\%$ \\
\hline Questions & 0 & $0 \%$ & 13 & $24 \%$ & 29 & $49 \%$ & 19 & $37 \%$ & 3 & $7 \%$ & 4 & $10 \%$ \\
\hline Requests & 0 & $0 \%$ & 4 & $7 \%$ & 6 & $10 \%$ & 8 & $16 \%$ & 2 & $5 \%$ & 2 & $5 \%$ \\
\hline Disagreement/criticism & 3 & $43 \%$ & 15 & $27 \%$ & 19 & $32 \%$ & 15 & $29 \%$ & 18 & $44 \%$ & 18 & $46 \%$ \\
\hline Interruption & 4 & $57 \%$ & 23 & $42 \%$ & 5 & $8 \%$ & 3 & $6 \%$ & 13 & $32 \%$ & 15 & $38 \%$ \\
\hline Refusal & 0 & $0 \%$ & 0 & $0 \%$ & 0 & $0 \%$ & 6 & $12 \%$ & 5 & $12 \%$ & 0 & $0 \%$ \\
\hline Total & 7 & & 55 & & 59 & & 51 & & 41 & & 39 & \\
\hline
\end{tabular}






Fig. 3. Mixed messages and functions in 21 st-century comedies.

One last note relates to cases of impoliteness, which quite unexpectedly showed up in the comedies, with the forms scusa or chiedo scusa. This is the case of example (31) where a mother asks her daughter to apologize, but she blatantly refuses.

(31) Elisa: Tina per favore, chiedi scusa alla signora!

Tina: Io non chiedo scusa a nessuno! (Aronne, La vedova nera)

'Elisa: Tina, please, apologize to this Lady.

Tina: I do not apologize to anybody!'

As regards the 18th century comedies, it is interesting to note that frequencies are rather different and forms seem to be preferred in specific contexts (cf. Table 5 and Fig. 4, respectively).

Table 5

(Im)politeness in 18th century comedies.

\begin{tabular}{|c|c|c|c|c|c|c|c|c|c|c|c|c|}
\hline XVIII & scusate & $\%$ & scusatemi & $\%$ & chiedo/domando scusa & $\%$ & scusi & $\%$ & mi scusi/la scusi & $\%$ & mi scuso & $\%$ \\
\hline Politeness & 3 & $10 \%$ & 5 & $10 \%$ & 32 & $44 \%$ & 0 & $0 \%$ & 1 & $7 \%$ & 0 & $0 \%$ \\
\hline Mixed messages & 21 & $70 \%$ & 40 & $77 \%$ & 18 & $25 \%$ & 10 & $83 \%$ & 13 & $87 \%$ & 1 & $100 \%$ \\
\hline Mock politeness & 6 & $20 \%$ & 7 & $13 \%$ & 19 & $26 \%$ & 2 & $17 \%$ & 1 & $7 \%$ & 0 & $0 \%$ \\
\hline Impoliteness & 0 & $0 \%$ & 0 & $0 \%$ & 4 & $5 \%$ & 0 & $0 \%$ & 0 & $0 \%$ & 0 & $0 \%$ \\
\hline Total & 30 & $100 \%$ & 52 & $100 \%$ & 73 & $100 \%$ & 12 & $100 \%$ & 15 & $100 \%$ & 1 & $100 \%$ \\
\hline
\end{tabular}

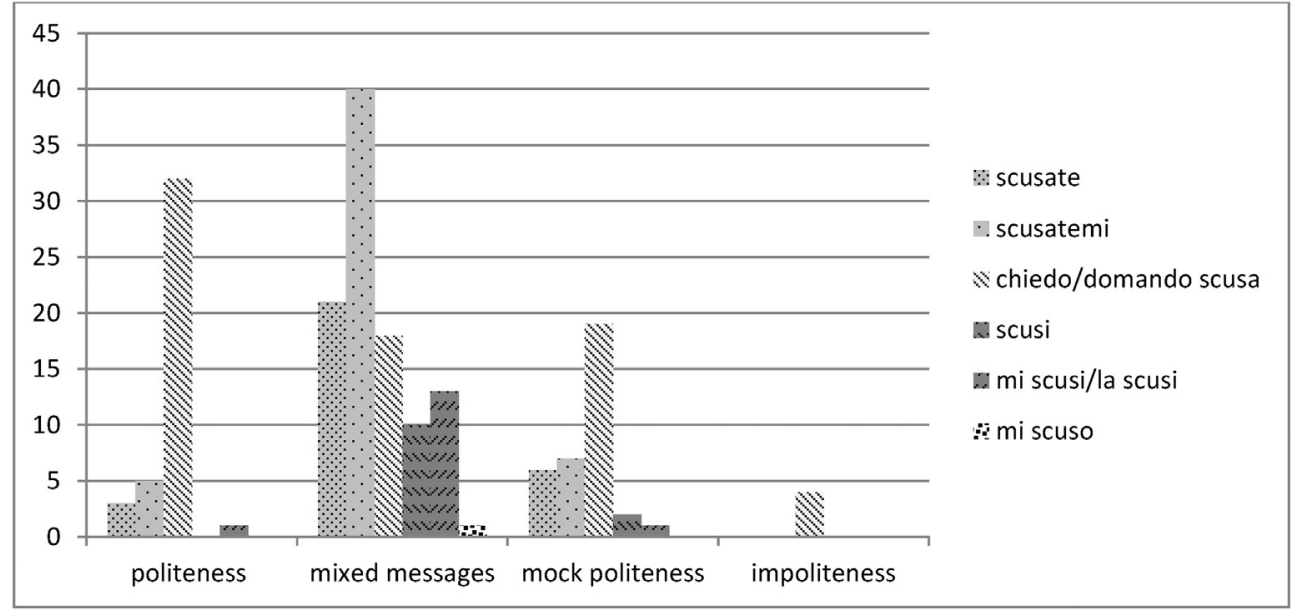

Fig. 4. Different forms and functions in 18th-century comedies. 
There is a marked preference for the performative locutions (chiedo/domando scusa) to take on a genuine politeness value (ex. 32). Instead, in mixed messages the delocutive verbs scusate(mi) or (mi/la)scusi are prevalent (cf. 33-35).

(32) No, caro signor Alberto; anzi vi chiedo scusa de' miei troppo ingiusti sospetti. (Goldoni, L'avvocato veneziano)

'No, Sir Alberto; on the contrary I apologize for my many unfair suspicions'

(33) LIN. Scusatemi, signore, sarete voi per avventura il signor Don Federico? (Goldoni, Gli amori di Zelinda e Linoro).

'Excuse me, Sir, are you by chance Don Federico?'

(34) ROB. Anche voi partite? (al Conte)

'Are you leaving as well (to the Count)'

CON. Domando scusa se non fo il mio dovere. [...] (saluta e parte) (Goldoni, La dama)

'I apologize for not doing my duty. (he waves goodbye and leaves)'

(35) POL. È permesso?

'Can I come in?'

OLIM. È permesso.

'you can'

POL. Scusate. 'I apologize'

OLIM. Vi ho scusato. 'You are apologized' (Goldoni, L'amore in caricatura)

Considering the social relevance of the complimento di scuse in the 18th century, it is not by chance that the only instances of impolite messages were enacted via the performative locutions (36).

(36) Perdono? poverino! Questa cosa tra femmine non s'usa. Prima vorrei morir che chieder scusa (Goldoni, Lo speziale)

'Forgiveness? Poor you! This thing is not common among women. I would rather die than apologize'

The ceremonious etiquette of the 18th century becomes paramount also in explaining the mock polite uses which are rather frequent and distributed among the different forms with the exception of mi scuso.

(37) Oh scusate signore, non vi aveva veduto. (mostra di voltarsi a caso e di veder Roberto)

(Goldoni, Gli amori di Zelinda e Linoro)

'Oh I apologize Sir, I did not see you. (He pretends to turn around by chance and to see Roberto'

(38) vi domando scusa, e vi prometto di non inquietarvi mai più. (Bisogna farsi un merito della necessità.)

(Goldoni, Gli amori di Zelinda e Linoro)

'Zelinda, I beg your pardon and promise you I will not upset you anymore (You have to

make the best of a bad situation)'

As regards the details of mixed messages and functions, the data offer a very interesting picture, as what emerges is that mixed messages are mainly used by speakers for politic behaviour, with the only exception being scusate which is also frequently used to mitigate a criticism (cf. Table 6 and Fig. 5, respectively).

Table 6

Mixed messages and functions in 18th-century comedies.

\begin{tabular}{|c|c|c|c|c|c|c|c|c|c|c|c|c|}
\hline XVIII & scusate & $\%$ & scusatemi & $\%$ & chiedo scusa & $\%$ & scusi & $\%$ & mi/la scusi & $\%$ & mi scuso & $\%$ \\
\hline Politic & 16 & $80 \%$ & 16 & $40 \%$ & 17 & $94 \%$ & 2 & $20 \%$ & 9 & $64 \%$ & 1 & $100 \%$ \\
\hline Suggestion & 0 & $0 \%$ & 0 & $0 \%$ & 0 & $0 \%$ & 0 & $0 \%$ & 2 & $14 \%$ & 0 & $0 \%$ \\
\hline Criticism & 3 & $15 \%$ & 17 & $43 \%$ & 0 & $0 \%$ & 0 & $0 \%$ & 1 & $7 \%$ & 0 & $0 \%$ \\
\hline Question & 0 & $0 \%$ & 2 & $5 \%$ & 0 & $0 \%$ & 2 & $20 \%$ & 0 & $0 \%$ & 0 & $0 \%$ \\
\hline Refusal & 1 & $5 \%$ & 5 & $13 \%$ & 1 & $6 \%$ & 6 & $60 \%$ & 1 & $7 \%$ & 0 & $0 \%$ \\
\hline Total & 20 & & 40 & & 18 & & 10 & & 14 & & 1 & \\
\hline
\end{tabular}

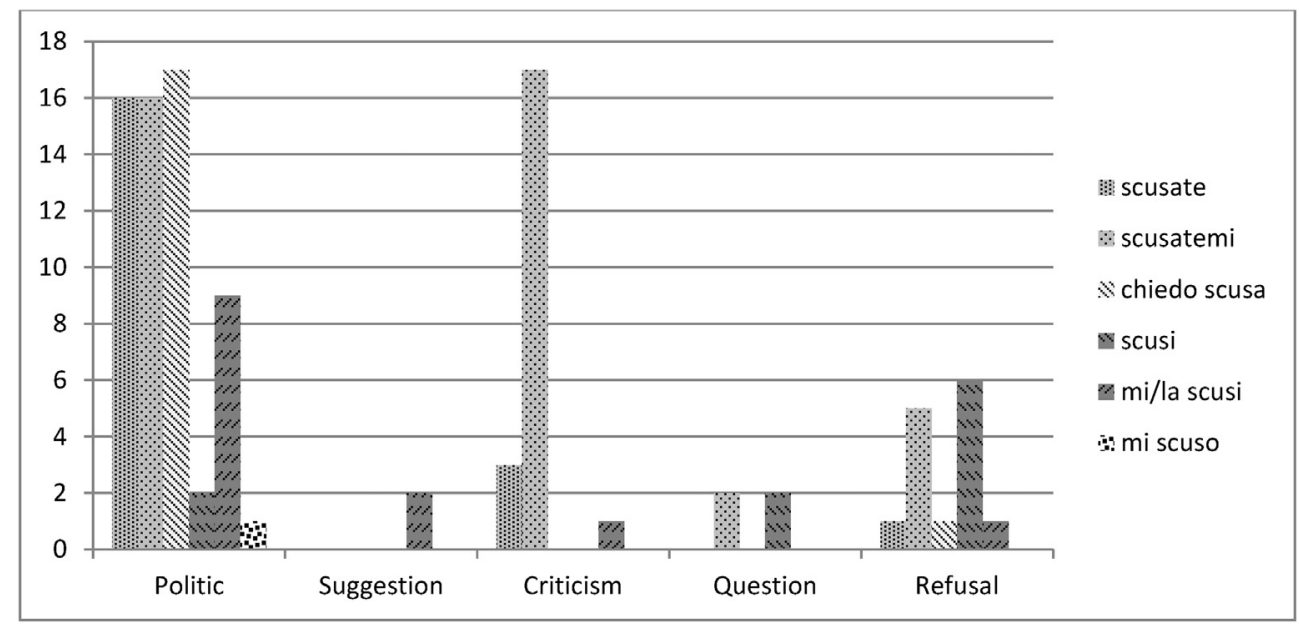

Fig. 5. Mixed messages and functions in 18th-century comedies. 
More frequent forms used are again scusate(mi) and chiedo scusa. These data also confirm the importance of norms of etiquette for speakers in the 18th century. For instance many of these uses relate to greetings since people entering a room usually greeted by apologising for their presence (ex. 39).

(39) Bea: Ma ecco il signor Alberto. "Here is Mr. Alberto"

ALB. Ghe domando scusa, se me son preso l'ardir d'incomodarla. "I apologize if I am disturbing you" (Goldoni, L'avvocato veneziano)

\section{Conclusions}

The analysis of scus-apologies revealed a number of interesting elements. We now return to the question in the Introduction in an attempt to answer each in turn.

As far as question 1 is concerned, i.e. variation in time, today scusa is the unmarked form used by speakers for genuine and ritualistic apologies alike. Diachronically the form in apologies is rather new, for its first attestation in apologies can be traced back to the beginning of the 19th century. In the 18th century plays it is decidedly peripheral. In those comedies, the unmarked form is the locution chiedo scusa which seems specialized in genuinely polite messages. Contemporary scusa probably developed thanks to the mixed nature of apologies, i.e. their strategic as well as their normative values. In the 18 th century apologies, like many other speech acts, were enacted through a wide range of fixed phrases and formulaic routines which enabled speakers to maintain a balance between social obligation and personal interest. Situational appropriateness was achieved through these formulae which speakers consciously differentiated according to the context, their interlocutors (i.e. their social status), and the social importance of the apology. The need for appropriateness is at the base of frequency of such forms. This frequency, required by the ceremonious etiquette of the grand siecle, is what probably favoured the routinization of chiedo scusa into Contemporay Italian scusa.

As regards question 2, i.e. the analysis of more ritualized forms in the two centuries, data show how the mixed nature of apologies influences their use in different types of (im)polite messages as speakers frequently use them to enact mixed polite messages, while impoliteness is relegated to a peripheral role. This has probably to do with the nature of communication exchange where the need to acknowledge the positive face of the interlocutor is felt to be less important than the need to accomplish other speech acts which are mostly favourable for the speaker. In this regard it is also interesting to note that this also seems to have a formal correlate in the 21 st century data as more frequent forms are the crystallized form scusa and the delocutive verbs, which are all second-person oriented apologies. On the contrary today performatives, which are firstperson-oriented apologies, are less frequent, probably because they imply a more direct commitment of the speaker, and therefore threaten his/her positive image. On the contrary, in the 18th century the performative locution chiedo scusa was very frequent which suggests a change in politeness strategies from expressions which are more related to the speaker's stance to those which imply a lower degree of speakers' commitment. This substitution implies deep changes in the communicative patterns which will need to be further analysed for instance taking into consideration the role of apologetic speech acts in the area of a culturally bound repertoire of sociopragmatic habiti, and the role of Italian as a mediator between Latin customs and new global behaviour.

Finally, in relation to question 3, i.e. more common forms in mock polite messages, it is interesting to note that mock politeness can be correlated with greater use of more formal and deferential variants in both centuries. Their deferential nuance enables speakers to distance themselves from their interlocutors and the excessive use of polite strategies (hyperpoliteness) triggers a sarcastic reading.

The forms that enact this type of message have however changed with time. This shows how the parameter of social distance is relevant for the choice of different strategies along the politeness - impoliteness continuum, but also how deferent forms in a highly ritualized society seem to favour mock politeness. This suggests that speakers consider conventions to be more important than linguistic forms.

\section{References}

Aijmer, Karin, 1996. Conversational Routines in English. Routledge, London.

Benveniste, Emile, 1958. Les verbes délocutifs. In: Hatcher, A.G., Selig, K.-L. (Eds.), Studia Philologica et litteraria in honorem L. Spitzer. Francke, pp. 5-63. Blum-Kulka, Shoshana \& House, Juliane \& Kasper, Gabriele, 1989. Cross-Cultural Pragmatics: Requests and Apologies. Ablex, Norwood.

Brown, Penelope, Levinson, Stephen C., 1987. Politeness: Some Universals in Language Usage. CUP, Cambridge.

Businaro, Barbara, 2002. Lo scusarsi tra convenzione e conversazione. Studi Ital. Linguist. Teor. Appl. 31/3, 471-502.

Costa, Bozzone, Rosella, Ghezzi, Chiara, Piantoni, Monica, 2014. Nuovo Contatto. A1. Loescher, Torino.

Coulmas, Florian, 1981. Poison to your soul. Thanks and apologies contrastively viewed. In: Coulmas, F. (Ed.), Conversational Routine. Mouton, The Hague, pp. 69-91.

Culpeper, Jonathan, 2001. Language and Characterisation in Plays and Texts. Routledge, London.

Culpeper, Jonathan, 2011. Impoliteness. CUP, Cambridge.

Dardano, Maurizio e Trifone, Pietro, 1997. La Nuova Grammatica Della Lingua Italiana. Zanichelli, Bologna.

Deutschmann, Mats, 2003. Apologizing in British English. PhD Thesis. University of Ume, Ume.

Fedriani, Chiara, Molinelli, Piera, 2017. Italian MA + IMPERATIVE between pragmatic markers and interjections: the rise and productivity of a pragmatic collostruction. In: Paper Presented at the International Workshop “Discourse Markers in Romance Languages: Boundaries and Interfaces" (Université catholique de Louvain 8-10 November 2017).

Fraser, Bruce, 1981. Conversational mitigation. JoP 4/4, 341-350.

Fraser, Bruce, 1990. Perspectives on politeness. JoP 14/2, 219-236. 
Goffman, Erving, 1971. Relations in Public: Microstudies of the Public Order. Allen Lane, London.

Haugh, Michael, 2014. Im/politeness Implicatures. Mouton, Berlin.

Held, Gudrun, 2005. Politeness in Italy. In: Hickey, L., Stewart, M. (Eds.), Politeness in Europe. Multilingual Matters, Clevendon, pp. $292-305$.

Leech, Geoffrey, 1983. Principles of Pragmatics. Longman, New York.

Leech, Geoffrey, 2014. The Pragmatics of Politeness. OUP, Oxford.

Molinelli, Piera, 2015. Polite forms and sociolinguistic dynamics in contacts between varieties of Italian. In: Consani, C. (Ed.), Contatto interlinguistico fra presente e passato. LED, Milano, pp. 283-313 (a cura di).

Murphy, James, 2015a. Revisiting the apology as a speech act. J. Lang. Polit. 14/2, 175-204.

Murphy, James, 2015b. How politicians use 'I'm sorry' to position themselves as not being sorry. In: Paper Given at the 14th IPrA Conference, Antwerp, 26-31 July 2015.

Norrick, Neal R., 1978. Expressive illocutionary acts. JoP 2/3, 277-291.

Ogiermann, Eva, 2009. Politeness and in-directness across cultures. J. Politeness Res. 5/2, $189-216$.

Olshtain, Elite, 1989. Apologies across languages. In: Blum-Kulka, S., House, J., Kasper, G. (Eds.), Cross-Cultural Pragmatics: Requests and Apologies. Ablex, Norwood, pp. 155-173.

Olshtain, Elite, Cohen, Andrew D., 1983. Apology: a speech act set. In: Wolfson, N., Judd, E. (Eds.), Sociolinguistics and Language Acquisition. Newbury House, Rowley MA, pp. 18-35.

Robinson, Jeffrey, 2004. The sequential organization of 'explicit' apologies in naturally occurring English. Res. Lang. Soc. Interact. 37, $291-330$.

Suchomel, Vít, Pomikálek, Jan, 2012. Efficient Web crawling for large text corpora. In: Proc Seventh Web as Corpus Workshop (WAC7), 39-43. Lyon, France. Retrieved at. https://nlp.fi.muni.cz/ xsuchom2/papers/PomikalekSuchomel_SpiderlingEfficiency.pdf.

Taylor, Charlotte, 2016. Mock Politeness in English and Italian: a Corpus-assisted Metalanguage Analysis. Benjamins, Amsterdam.

TLIO = Tesoro Della Lingua Italiana Delle Origini http://tlio.ovi.cnr.it/.

Tommaseo, Niccolò, Bellini, Bernardo, 1861-1879. Dizionario Della Lingua Italiana. www.tommaseobellini.it.

Tosi, Arturo, 2001. Language and Society in a Changing Italy. Clevedon, Multilingual Matters Vocabolario Degli Accademici Della Crusca, 1729-1738, IV Edizione. http://www.lessicografia.it/ricerca_libera.jsp.

Watts, Richard, 2003. Politeness. CUP, Cambridge.

Zimin, Susan, 1981. Sex and politeness: factors in first- and second-language use. Int. J. Sociol. Lang. 27, 35-58.

Chiara Ghezzi is currently a Post-Doc researcher at the University of Bergamo. She holds a PhD in Linguistics received from the University of Pavia, Italy. Prior to her current position, she has been a Research fellow at the University of Bergamo. Her research interests span across sociolinguistic variation and variational pragmatics, socio-historical pragmatics, history of Italian, discourse and pragmatic markers, grammaticalization and pragmaticalization theory. She co-edited the volumes Discourse and Pragmatic Markers from Latin to the Romance Languages 2014, OUP, and Positioning the Self and Others: Linguistic Perspectives, 2018, Benjamins.

Piera Molinelli is Professor of General Linguistics at the University of Bergamo, Italy. Her main areas of research relate to diachronic and historical linguistics, Latin linguistics, and the history of Latin and Old Italian, socio-historical pragmatics, historical contact linguistics. She is the author of Fenomeni della negazione dal latino all'italiano, 1988, La Nuova Italia, along with a number of journal articles and book chapters, and is co-editor, among others, of Synchrony and Diachrony: A dynamic interface, 2013, Benjamins, Plurilinguismo e diglossia nella Tarda Antichità e nel Medioevo, 2013, Discourse and Pragmatic Markers from Latin to the Romance languages, 2014, OUP, Language and Identity in Multilingual Mediterranean settings. Challenges for Historical Sociolinguistics, 2017, Mouton de Gruyter, and Positioning the Self and Others: Linguistic Perspectives, 2018, Benjamins. 